\title{
Relationships Between Milk Urea and Production, Nutrition, and Fertility Traits in Israeli Dairy Herds
}

\author{
D. Hojman, ${ }^{1}$ O. Kroll, ${ }^{2}$ G. Adin, ${ }^{1}$ M. Gips, ${ }^{3}$ B. Hanochi, ${ }^{4}$ and E. Ezra ${ }^{4}$ \\ ${ }^{1}$ Dairy Cattle Department-Extension Service, \\ Ministry of Agriculture and Rural Development, \\ Bet Dagan 50150 Israel \\ 2"Hachaklait" Society for Veterinary Services, \\ Caesaria Industrial Park, Israel \\ ${ }^{3}$ Central Milk Laboratory, Israel Cattle Breeders' Association, \\ Caesaria Industrial Park, Israel \\ ${ }^{4}$ Herdbook Data Center, Israel Cattle Breeders' Association, \\ Caesaria Industrial Park, Israel
}

\begin{abstract}
The objectives of this study were to identify and evaluate production and environmental factors that influence milk urea (MU) in Israeli dairy herds, to analyze the relationships between MU concentration and nutritional variables, and to examine a possible association between MU and pregnancy rate (PR). Production and environmental data were obtained from the Israeli Dairy Herd Improvement (DHI) Center ( $\mathrm{n}=1,279,600)$. Programmed total mixed rations (feeds and quantities) on milk-test day were collected from 42 dairy herds. Data on 36,073 cows that were inseminated close to milk-test day and pregnancy diagnosis results were obtained from the DHI data bank. Highly significant positive relationships were found between MU concentration and milk yield and fat percentage; relationships between MU and milk total protein percentage and somatic cell count were negative. Milk urea levels were higher during the summer months and were higher for adult cows. These levels increased as lactation progressed. Milk urea was positively associated with dietary levels of crude protein, ruminal digestible protein, and neutral detergent fiber contents; it was negatively associated with ration energy and nonstructural carbohydrate contents. Significant influences of specific feeds on MU were detected. A significant negative association was found between MU level and PR. Least squares means for PR for cows in the lowest and highest MU quartiles were 38.4 and $36.1 \%$, respectively. Increasing levels of MU were negatively related to reproductive performance of dairy cows, but the risk of nonpregnancy caused by high levels of MU was lower than reported in previous studies.
\end{abstract}

Received September 8, 2003.

Accepted October 20, 2003.

Corresponding author: D. Hojman; e-mail: danhoj@shaham. moag.gov.il.
(Key words: milk urea, production, nutrition, fertility)

Abbreviation key: $\mathbf{M U}=$ milk urea, $\mathbf{N D F}_{\mathbf{f}}=\mathrm{NDF}$ from forage, $\mathbf{N D F}_{\text {non-f }}=$ NDF from sources other than forage, $\mathbf{P R}=$ pregnancy rate, $\mathbf{S U}=$ serum urea.

\section{INTRODUCTION}

Milk urea (MU) is highly correlated (0.88 to 0.98) with serum urea (SU) (Butler et al., 1996; Broderick and Clayton, 1997), and its level represents mainly ( $\mathrm{r}=$ 0.86) $\mathrm{N}$ losses from rumen fermentation (Hof et al., 1997). Several factors influence MU concentration: breed (Rodriguez et al., 1997), parity (Broderick and Clayton, 1997), BW (Kohn et al., 2001), milk yield (Godden et al., 2001), fat and protein content, DIM, and month of the year.

Nutritional factors that have major effects on MU concentration are dietary CP, RDP, RUP, energy:protein ratio, and NSC (Baker et al., 1995; Broderick and Clayton, 1997; Godden et al., 2001). However, few studies have dealt with the extent to which specific feeds influence MU level, information that may be useful when formulating balanced rations for dairy cows while attempting to minimize $\mathrm{N}$ losses.

Benefits of correcting for imbalances in dietary protein and energy supply may include increased production efficiency and reduction of avoidable $\mathrm{N}$ losses to the environment.

Another benefit of reducing SU levels relates to a possible improvement in the fertility performance of dairy herds. A negative effect of elevated concentrations of SU or MU on dairy cattle fertility has been widely reported (Gustafsson and Carlsson, 1993; Butler et al., 1995; Rajala-Schultz et al., 2000), and MU levels >19 $\mathrm{mg} / \mathrm{dL}$ have been associated with reduced reproductive performance. However, other studies (Howard et al., 1987; Garcia-Bojalil et al., 1998; Melendez et al., 2000) have not found any negative effects of MU on fertility. 
The objectives of this study were to identify and evaluate production and environmental factors that influence MU in Israeli dairy herds, to determine the relationships between MU concentration and nutritional variables, and to examine a possible association between MU level in cows close to insemination day and the correspondent pregnancy rate (PR).

\section{MATERIALS AND METHODS}

Data were obtained from the Israeli DHI Center's milk-recording program, which, in 2001, included $>90 \%$ of the dairy cows in the country $(n=104,660)$. For dairy farms milking 3 times/d (average per cow annual yield: $11,032 \mathrm{~kg}$ ), the sample was a mix from 2 of the 3 daily milkings, and for cows milked twice a day (average per cow annual yield: $9843 \mathrm{~kg}$ ), morning and afternoon samples were taken alternatively. Test-day milk samples were analyzed at the Central Milk Laboratory linked to the DHI Center for fat, total protein, and lactose percentages; SCC; and MU concentration. Measurement of MU has been routinely performed since mid 2000 by an automated infrared test method (Milkoscan 4000 and Milkoscan FTIR 6000 milk analyzer; Foss Electric, Hillerod, Denmark).

\section{Relationships Between Production and Environmental Factors and MU Concentration}

Data for this study (File 1) were obtained from testday measurements recorded by the Israeli DHI Center between September 2000 and December 2002 (n = $1,279,600)$. Two models were designed. Model 1 examined associations between production and environmental factors and MU concentration, and Model 2 analyzed production variables (milk yield, milk fat and total protein contents, and SCC) in different MU-level categories.

Relationships between milk yield, fat and total protein contents, SCC, and MU concentration. Laboratory results for MU, fat and total protein percentages, and SCC were combined with the corresponding daily milk yields, parity number, and calving date. General effects were calculated using PROC GLM (SAS, 1999-2001). Model 1 was $\mathrm{Y}_{\mathrm{ijkl} m n}=\mu+\mathrm{MD}_{\mathrm{i}}+\mathrm{YD}_{\mathrm{j}}+$ $\mathrm{HYD}_{\mathrm{kj}}+\mathrm{MF}_{\mathrm{l}}+\mathrm{CDIM}_{\mathrm{m}}+\mathrm{L}_{\mathrm{n}}+\left(\mathrm{L}^{*} \mathrm{CDIM}\right)_{\mathrm{mn}}+\mathrm{M}_{\mathrm{ijklmn}}+$ $\mathrm{PF}_{\mathrm{ijklmn}}+\mathrm{PP}_{\mathrm{ijklmn}}+\mathrm{SCC}_{\mathrm{ijklmn}}+\mathrm{e}_{\mathrm{ijklmn}}$, where $\mathrm{Y}_{\mathrm{ijklmn}}=$ MUN, $\mu=$ overall mean, $\mathrm{MD}_{\mathrm{i}}=$ month of milk recording ( $\mathrm{i}=1$ to $12, \mathrm{YD}_{\mathrm{j}}=$ year of milk recording $(\mathrm{j}=2000,2001$, or 2002), $\mathrm{HYD}_{\mathrm{kj}}=$ herd-year of milk reording $(\mathrm{k}=1$ to 966), $\mathrm{MF}_{1}=$ month of calving $(\mathrm{l}=1$ to 12$), \mathrm{CDIM}_{\mathrm{m}}=$ months in milk ( $\mathrm{m}=1$ to 15$), \mathrm{L}_{\mathrm{n}}=$ parity $(\mathrm{n}=1,2,3$, and $>3$ ), $\mathrm{M}_{\mathrm{ijklmn}}=$ test-day kilograms of milk, $\mathrm{PF}_{\mathrm{ijklmn}}=$ test-day fat percentage, $\mathrm{PP}_{\mathrm{ijk} k \mathrm{mn}}=$ test-day protein per- centage, $\mathrm{SCC}_{\mathrm{ijklmn}}=$ test-day $\mathrm{SCC}$, and $\mathrm{e}_{\mathrm{ijklmn}}=$ random residual.

Milk yield, fat and total protein contents, and SCC for different MU categories. File 1 was divided into four quartiles of equal size with respect to $\mathrm{MU}$ concentration. The MUN values for the different quartiles were: lowest quartile $\left(\mathrm{MU}_{1}\right),<11.75 \mathrm{mg}$ of $\mathrm{MUN} / \mathrm{dL}$; 2nd lowest quartile $\left(\mathrm{MU}_{2}\right), 11.75$ to $14.09 \mathrm{mg}$ of MUN/dL; 2nd highest quartile $\left(\mathrm{MU}_{3}\right), 14.10$ to 16.92 $\mathrm{mg}$ of $\mathrm{MUN} / \mathrm{dL}$, and highest quartile $\left(\mathrm{MU}_{4}\right),>16.92 \mathrm{mg}$ of MUN/dL. For each MU quartile we had, from the GLM, the least squares means for each of the production traits. By using this method, we could analyze milk yield, fat and total protein contents, and SCC for the different levels of MU.

Model 2 was $\mathrm{Y}_{\mathrm{ijklmno}}=\mu+\mathrm{MD}_{\mathrm{i}}+\mathrm{YD}_{\mathrm{j}}+\mathrm{H}(\mathrm{YD})_{\mathrm{kj}}+\mathrm{MF}_{\mathrm{l}}$ $+\mathrm{CDIM}_{\mathrm{m}}+\mathrm{L}_{\mathrm{n}}+(\mathrm{L} * \mathrm{CDIM})_{\mathrm{mn}}+\mathrm{GMUN}_{\mathrm{o}}+\left(\mathrm{GMUN}^{*} \mathrm{CDI}-\right.$ $\mathrm{M})_{\text {om }}+(\text { GMUN*L })_{\text {on }}+\mathrm{e}_{\mathrm{ijk} k \mathrm{mno}}$, where $\mathrm{Y}=$ test-day kilograms of milk, fat percentage, protein percentage, or SCC; GMUN $_{0}=$ MUN category (o = 1 to 4 ); and the other terms were as defined previously.

\section{Relationships Between Nutritional Parameters and MU Concentration}

Managerial and nutritional practices are similar in most Israeli dairy farms. Cows are kept indoors in openshade barns (12 to $20 \mathrm{~m}^{2}$ per cow) or free-stall barns and are fed a TMR $\geq 1$ times daily. Rations are formulated using linear programs and usually include $>15$ ingredients. Large dairy farms prepare their own TMR, and smaller ones purchase prepared TMR from regional feed centers. The TMR are fed to allow 3\% orts, and feed is regularly 'pushed up' during the daytime. Milking cows are usually grouped by parity (primiparous separated from adult cows). In most herds, the relatively small number of cows makes it impractical to manage differentiated rations; hence, cows are generally fed the same diet throughout lactation.

Data for this research included two data subsets. One consisted of MU herd least squares means (Model 1) for 175 cooperative dairy farms (average cows in milking = 268; $3 \times /$ d) from the November 2000 DHI test. Among them, 15 herds with the highest, 14 herds with the lowest, and another 5 herds with average MU concentrations were selected; the second data subset included MU herd least squares means (Model 1) from 8 dairy farms during 7 subsequent monthly milk tests. For each herd and for each month (i.e., the herd-month ration) of both data subsets ( $\mathrm{n}=90$ herd-months), the programmed TMR (feedstuffs and quantities) fed to the milking herd on the monthly test day was obtained. Correspondence between the programmed ration and the de facto prepared ration was checked with herd 
Table 1. Mean and standard deviation of milk yield, fat and total protein percentages, milk urea concentration, and SCC per lactation number.

\begin{tabular}{|c|c|c|c|c|c|c|c|c|c|c|c|}
\hline \multirow{2}{*}{$\begin{array}{l}\text { Lactation } \\
\text { number }\end{array}$} & \multirow[b]{2}{*}{$\mathrm{n}$} & \multicolumn{2}{|c|}{ Milk } & \multicolumn{2}{|c|}{ Fat } & \multicolumn{2}{|c|}{ Total protein } & \multicolumn{2}{|c|}{ Milk urea } & \multicolumn{2}{|c|}{ SCC } \\
\hline & & Mean & $\mathrm{SD}$ & Mean & $\mathrm{SD}$ & Mean & SD & Mean & SD & Mean & SD \\
\hline & & \multicolumn{2}{|c|}{$(\mathrm{kg})$} & \multicolumn{2}{|c|}{$(\% / \mathrm{kg})$} & \multicolumn{2}{|c|}{$(\% / \mathrm{kg})$} & \multicolumn{2}{|c|}{ (mg of MUN/dL) } & \multicolumn{2}{|c|}{$(\times 1000 / \mathrm{mL})$} \\
\hline 1 & 452,535 & 30.6 & 6.2 & 3.49 & 0.64 & 3.21 & 0.33 & 14.4 & 4.0 & 208 & 582 \\
\hline 2 & 340,299 & 35.5 & 9.3 & 3.46 & 0.69 & 3.21 & 0.35 & 14.9 & 4.2 & 256 & 698 \\
\hline 3 & 227,288 & 37.3 & 10.5 & 3.44 & 0.70 & 3.15 & 0.34 & 14.7 & 4.2 & 348 & 878 \\
\hline 4 & 259,478 & 36.9 & 10.8 & 3.40 & 0.69 & 3.08 & 0.34 & 14.6 & 4.3 & 503 & 1165 \\
\hline
\end{tabular}

managers and their consultant nutritionists. Data were considered valid if the ration on the test day had been fed for at least $1 \mathrm{wk}$. The composition profile of purchased commercial products included in the rations (complete feeds, premixes) was obtained, and the proportional amount of each component was attributed to the corresponding feed ingredient. Rations were standardized at $20 \mathrm{~kg}$ of DM.

Nutritional effects on MU were examined by two approaches. One approach tested associations between groups of feeds with similar nutritional characteristics and MU, and the other examined relationships between chemical composition of rations and MU. A total of 46 different feedstuffs were used in the 90 herd-month rations. To avoid multiple comparisons and enable a significant statistical analysis of the associations between feeds and MU concentrations, feedstuffs were merged into 17 groups (see Table 3 further down) according to type of starch, NDF, and protein; special consideration was given to their degradability and digestibility (Orskov, 1989). The resulting data file (File 2a) included the quantified dietary composition of the 90 herd-month rations (see Table 4 further down). General effects for each of the feed groups on MU were calculated by using the GLM procedure. The dependent variable was $\mathrm{MU}$, and the independent variables were number of data subset (1 or 2) and each one of the feed groups at a time. An additional data file (File 2b) consisted of the chemical compositions of the herdmonth rations, which were calculated using a common matrix of nutritional values. The following nutritional parameters were considered for each feed and for the total ration: $\mathrm{NE}_{\mathrm{L}}, \mathrm{CP}, \mathrm{RUP}, \mathrm{RDP}, \mathrm{NDF}, \mathrm{NDF}$ from forage $\left(\mathbf{N D F}_{\mathbf{f}}\right), \mathrm{NDF}$ from sources other than forage $\left(\mathbf{N D F}_{\text {non-f }}\right)$, and NSC. Values for $\mathrm{NE}_{\mathrm{L}}$ were obtained mainly from the NRC (1989); CP and NDF contents were average results from local laboratory tests; RUP and RDP percentages in CP were commonly accepted values from published investigations or available results from local analyses. Files $2 \mathrm{a}$ and $2 \mathrm{~b}$ were merged with File 1 at the herd level. General effects for the nutritional parameters on MU were calculated using the GLM procedure. The dependent variable was MU, and the independent variables were number of data subset ( 1 or 2 ) and each one of the nutritional parameters at a time.

\section{Relationship Between MU Level of Cows at Insemination and PR}

Dairy cows in Israel are regularly inseminated by AI technicians, and pertinent information (number of cows, date) is recorded and automatically incorporated in the DHI Center data bank. Pregnancy diagnosis is performed by herd veterinarians approximately $45 \mathrm{~d}$ after insemination by per rectum palpation, and results are communicated to the DHI Center. Calving difficulty and calf mortality at birth are regularly reported by the farmers to the DHI Center.

A data file (File 3) was composed by scanning the DHI Center data bank to detect cows that had been inseminated (1st to 3 rd inseminations) within $\pm 5 \mathrm{~d}$ from a test-day control and merging the data with File 1. Parameters considered for this study were MU concentration and milk yield in the corresponding milk control, herd, breeding date (month, year), dystocia at previous calving, insemination number, and parity.

Model 3 analyzed the effects of groups of MUN on PR. Pregnancy rate was defined as the number of pregnant cows divided by the total number of AI. Milk urea was divided into the same quartiles as in Model 2. Model 3 had the following effects: $\mathrm{PR}_{\mathrm{ijk} \text { lmno }}=\mu+\mathrm{CD}_{\mathrm{i}}+\mathrm{NI}_{\mathrm{j}}+$ $\mathrm{YD}_{\mathrm{k}}+\mathrm{H}(\mathrm{YD})_{\mathrm{lk}}+\mathrm{MI}_{\mathrm{m}}+\mathrm{L}_{\mathrm{n}}+\mathrm{GMUN}_{\mathrm{o}}+\left(\mathrm{L}^{*} \mathrm{YD}\right)_{\mathrm{nk}}+$ $(\mathrm{GMUN} * \mathrm{~L})_{\mathrm{on}}+(\mathrm{GMUN} * \mathrm{NI})_{\mathrm{oj}}+(\mathrm{L} * \mathrm{NI})_{\mathrm{nj}}+\left(\mathrm{GMUN} * \mathrm{~L}^{*}\right.$ $\mathrm{NI})_{\text {onj }}+\mathrm{DI}+\mathrm{M}+\mathrm{e}_{\mathrm{ijklmno}}$, where $\mathrm{PR}_{\mathrm{ijklmno}}=$ pregnancy rate $(\mathrm{PR}=100$ if the result of the insemination is pregnancy and $\mathrm{PR}=0$ otherwise), $\mathrm{CD}_{\mathrm{i}}=$ dystocia at previous calving $(\mathrm{i}=1$ or 2$), \mathrm{NI}_{\mathrm{j}}=$ number of insemination $(\mathrm{j}=$ $1,2$, or 3$), \mathrm{YD}_{\mathrm{k}}=$ year of insemination $(\mathrm{k}=2000,2001$, or 2002), $\mathrm{MI}_{\mathrm{m}}=$ month of insemination ( $\mathrm{m}=1$ to 12$)$, $\mathrm{L}_{\mathrm{n}}=$ parity $(\mathrm{n}=1$ or $>1), \mathrm{DI}=$ number of days from calving to insemination, and the other terms were as defined previously.

\section{RESULTS}

Milk urea concentrations are presented as MUN (mg/ $\mathrm{dL}$ ). The overall unadjusted mean MUN concentration 
Table 2. Effects and significance of multivariate regression model describing the relationship between MUN concentration $(\mathrm{mg} / \mathrm{dL})$ at cow level and production variables, parity, month of lactation, and month of test day.

\begin{tabular}{|c|c|c|c|}
\hline Effect & Estimate & $\mathrm{SE}$ & $P$ \\
\hline Intercept & 10.03 & 0.11 & 0.001 \\
\hline Milk yield, kg/d per cow & 0.024 & 0.0005 & 0.001 \\
\hline Milk fat, \%/kg & 1.235 & 0.005 & 0.001 \\
\hline Milk total protein, $\% / \mathrm{kg}$ & -1.035 & 0.012 & 0.001 \\
\hline $\mathrm{SCC}, \times 1000 / \mathrm{mL}$ & -0.0005 & 0.000004 & 0.001 \\
\hline \multicolumn{4}{|l|}{ Parity } \\
\hline 1 & 0.23 & 0.07 & 0.01 \\
\hline 2 & 0.42 & 0.08 & 0.001 \\
\hline 3 & -0.21 & 0.09 & NS \\
\hline$>3$ & 0 & & \\
\hline \multicolumn{4}{|l|}{ Month of lactation } \\
\hline 1 & 0.13 & 0.07 & 0.001 \\
\hline 2 & -0.99 & 0.07 & 0.001 \\
\hline 3 & -0.58 & 0.07 & 0.001 \\
\hline 4 & -0.14 & 0.07 & 0.001 \\
\hline 5 & 0.15 & 0.07 & 0.001 \\
\hline 6 & 0.37 & 0.07 & 0.001 \\
\hline 7 & 0.44 & 0.07 & 0.001 \\
\hline 8 & 0.51 & 0.07 & 0.001 \\
\hline 9 & 0.56 & 0.07 & 0.001 \\
\hline 10 & 0.58 & 0.07 & 0.001 \\
\hline 11 & 0.52 & 0.07 & 0.001 \\
\hline 12 & 0.39 & 0.07 & 0.001 \\
\hline 13 & 0.23 & 0.07 & 0.01 \\
\hline 14 & 0.12 & 0.07 & 0.15 \\
\hline 15 & 0 & & \\
\hline \multicolumn{4}{|l|}{ Month of test day } \\
\hline Jan & 1.65 & 0.02 & 0.05 \\
\hline Feb & 2.54 & 0.02 & 0.001 \\
\hline Mar & 2.36 & 0.02 & 0.001 \\
\hline Apr & 2.62 & 0.02 & 0.04 \\
\hline May & 3.11 & 0.02 & 0.02 \\
\hline Jun & 5.79 & 0.02 & 0.001 \\
\hline Jul & 3.76 & 0.02 & 0.001 \\
\hline Aug & 2.28 & 0.02 & 0.001 \\
\hline Sep & 2.17 & 0.02 & 0.001 \\
\hline Oct & 1.14 & 0.02 & 0.001 \\
\hline Nov & -0.46 & 0.02 & 0.001 \\
\hline Dec & 0 & & \\
\hline
\end{tabular}

Table 3. Feed group definitions and included feedstuffs.

\begin{tabular}{lll}
\hline Feed group & Feed group definition & Feedstuff \\
\hline 1 & High-degradable starch grains & Barley, wheat, rye \\
2 & Low-degradable starch grains & Maize, sorghum \\
3 & Winter crops harvested as hay & Barley, wheat \\
4 & Winter crops harvested as silage & Wheat \\
5 & Summer crops harvested as silage & Maize, sorghum \\
6 & Legumes harvested as hay & Alfalfa, vetch \\
7 & Protein from animal sources & Fish meal, feathers meal \\
8 & High-rate degradable protein & Cotton meal, sunflower meal, dry and wet corn gluten feed \\
9 & Medium-rate degradable protein & Soybean meal, rapeseed meal \\
10 & Low-rate degradable protein & Corn gluten meal \\
11 & High NSC feeds & Citrus pulp, Brewers grain wet \\
12 & Fibrous concentrate (high energy) & Cotton seeds, wheat bran \\
13 & Fibrous concentrate (low energy) & Soybean hulls \\
14 & Fat & Fat-calcium soaps, oil \\
15 & Molasses & Molasses \\
16 & NPN sources & Urea, ammonium sulfate \\
17 & Food additives & Minerals, vitamins, buffers, yeasts, salt \\
\hline
\end{tabular}


Table 4. Average dietary composition of rations, standardized to $20 \mathrm{~kg}$ of DM, by feed groups ${ }^{1}$, herd, and month for 42 commercial dairy herds ( $\mathrm{n}=90$ herd-rations).

\begin{tabular}{llllll}
\hline Feed group & $\mathrm{n}$ & Mean & $\mathrm{SD}$ & Minimum & Maximum \\
\hline & & & & & \\
\cline { 3 - 5 } 1 & 90 & 3.13 & 0.64 & 1.12 & \\
2 & 90 & 3.18 & 0.71 & 0.54 & 4.79 \\
3 & 79 & 0.64 & 0.43 & 0.39 & 5.46 \\
4 & 88 & 4.44 & 1.13 & 1.83 & 8.25 \\
5 & 45 & 1.10 & 1.21 & 0.72 & 5.08 \\
6 & 72 & 0.62 & 0.54 & 0.40 & 2.64 \\
7 & 49 & 0.10 & 0.12 & 0.90 & 0.37 \\
8 & 90 & 2.16 & 1.00 & 0.81 & 2.38 \\
9 & 90 & 1.40 & 0.38 & 0.77 & 0.71 \\
10 & 70 & 0.22 & 0.18 & 0.08 & 2.62 \\
11 & 25 & 0.30 & 0.52 & 0.46 & 3.38 \\
12 & 90 & 1.64 & 0.66 & 0.20 & 1.27 \\
13 & 45 & 0.34 & 0.41 & 0.03 & 0.52 \\
14 & 90 & 0.31 & 0.13 & 0.07 & 0.87 \\
15 & 32 & 0.21 & 0.29 & 0.20 & 0.21 \\
16 & 71 & 0.11 & 0.07 & 0.01 & 0.91 \\
17 & 90 & 0.55 & 0.13 & 0.24 & \\
\hline
\end{tabular}

${ }^{1}$ As described in Table 3.

at cow level was $14.4 \mathrm{mg} / \mathrm{dL}(\mathrm{SD}=4.0)$, and the range of MUN average concentrations at herd level was 6.9 to $21.5 \mathrm{mg} / \mathrm{dL}(\mathrm{SD}=2.12)$.

\section{Relationships Between Production and Environmental Factors and MU Concentration}

Average results for milk, fat and total protein percentages, MU concentration, and SCC are presented in Table 1.

Relationships between milk yield, fat and total protein contents, SCC, and MU concentration. All of the variables included in the model significantly $(P$ $<0.001)$ influenced MU concentration $\left(R^{2}=0.37\right)$ : year, herd, lactation number, month of test day, month of calving, DIM, DIM*lactation number, milk yield, fat and total protein percentages, and SCC.

Positive relationships (Table 2) were found between MU concentration and milk yield and milk fat percent- age; the relationships of MU with milk total protein percentage and SCC were negative. First lactation cows had lower MU levels than did second lactation cows. Least squares mean MU for parity 1, 2, 3, and $>3$ were $14.3,14.7,14.5$, and $14.5 \mathrm{mg}$ of MUN/dL, respectively. Milk urea concentration was significantly associated with month of the year; it was higher during the spring and summer months and lower in the cold season. The variation of MU during the year was a mirror image of the fluctuations in milk total protein percentage (Figure 1).

Milk yield, fat and total protein contents, and SCC in different MU categories. Milk yield, fat and total protein percentages, and SCC for different levels (quartiles) of MU in subsequent test-day controls (1 to 15) after calving were examined using Model 2; results are shown in Figures 2 through 5.

High MU levels were associated with high milk yields (Figure 2). At the first milk test after calving, least

Table 5. Effects and significance of univariate regression models describing the relationship between feed group ${ }^{1}$ content ( $\mathrm{kg}$ of DM) of rations fed to milking cows and test-day mean herd MUN concentration (mg/ dL).

\begin{tabular}{llrlll}
\hline Feed group & Feed group definition & Estimate & SE & $P$ & $\mathrm{r}^{2}$ \\
\hline 2 & Low-degradable starch grains & -1.29 & 0.52 & 0.02 & 0.08 \\
4 & Winter crops harvested as silage & 0.65 & 0.35 & 0.07 & 0.04 \\
5 & Summer crops harvested as silage & -0.74 & 0.36 & 0.04 & 0.07 \\
7 & Protein from animal sources & -6.63 & 4.68 & 0.16 & 0.04 \\
9 & Medium-rate degradable protein & -2.98 & 1.02 & 0.004 & 0.10 \\
10 & Low-rate degradable protein & 5.07 & 2.23 & 0.03 & 0.07 \\
13 & Fibrous concentrate (low energy) & 2.13 & 1.19 & 0.08 & 0.05 \\
14 & Fat & -5.26 & 2.87 & 0.07 & 0.05 \\
16 & NPN sources & 16.65 & 5.45 & 0.003 & 0.11 \\
17 & Food additives & -10.49 & 3.44 & 0.003 & 0.11 \\
\hline
\end{tabular}

${ }^{1}$ As described in Table 3. 
Table 6. Description of chemical composition of rations, standardized to $20 \mathrm{~kg}$ of DM, fed to milking cows by herd and month for 42 commercial dairy herds ( $\mathrm{n}=90$ herd-months).

\begin{tabular}{lllll}
\hline Nutritional variable & Mean & SD & Minimum & Maximum \\
\hline $\mathrm{NE}_{\mathrm{L}}$, Mcal & 35.0 & 0.6 & 33.6 & 36.2 \\
$\mathrm{CP}, \%$ of DM & 17.2 & 0.9 & 14.5 & 19.0 \\
$\mathrm{RDP}, \%$ of CP & 69.4 & 3.7 & 50.4 & 75.6 \\
$\mathrm{RUP}, \%$ of CP & 30.6 & 3.7 & 24.4 & 49.6 \\
$\mathrm{NDF}_{\mathrm{f}}, \%$ of DM & 17.9 & 1.2 & 15.6 & 23.1 \\
$\mathrm{NDF}_{\text {non-f }}, \%$ of DM & 15.0 & 1.5 & 11.5 & 48.0 \\
NSC, \% of DM & 37.1 & 2.3 & 30.9 & 2.6 \\
NSC:CP ratio & 2.1 & 0.2 & 1.7 & 0.6 \\
NSC:RDP ratio & 0.5 & 0.1 & 0.5 & 2 \\
\hline
\end{tabular}

${ }^{1} \mathrm{NDF}_{\mathrm{f}}=\mathrm{NDF}$ from forage; $\mathrm{NDF}_{\text {non-f }}=\mathrm{NDF}$ from sources other than forage.

squares mean milk yields for quartiles $\mathrm{MU}_{4}$ and $\mathrm{MU}_{1}$ were similar $(34.5 \mathrm{~kg} / \mathrm{d})$, but at lactation peak $(2 \mathrm{nd}$ milk test), there was a difference of $2.3 \mathrm{~kg} / \mathrm{d}$ between $\mathrm{MU}_{4}$ and $\mathrm{MU}_{1}$. This gap in milk yield progressively closed as lactation progressed, but persisted up to the 9th monthly milk test. At any of the first 8 milk tests, least squares mean milk yields were ordered correspondingly with MUN quartile levels. Calculated 305-d lactation milk yields were $10,226,10,426,10,488$. and $10,509 \mathrm{~kg}$ for quartiles $\mathrm{MU}_{1}, \mathrm{MU}_{2}, \mathrm{MU}_{3}$ and $\mathrm{MU}_{4}$, respectively.

Milk fat percentages maintained a consistent stratification in relation to MU concentration (Figure 3) in all milk tests. Average fat percentages for quartiles $\mathrm{MU}_{1}, \mathrm{MU}_{2}, \mathrm{MU}_{3}$, and $\mathrm{MU}_{4}$ were 3.37, 3.43, 3.47, and 3.55 , respectively. Calculated 305-d lactation fat yields were $340,355,364$, and $377 \mathrm{~kg}$ for $\mathrm{MU}_{1}, \mathrm{MU}_{2}, \mathrm{MU}_{3}$, and $\mathrm{MU}_{4}$, respectively.

The relationship between milk total protein percentage and MU concentration could be separated into two different phases (Figure 4). At the beginning of lactation, total protein percentages were ordered inversely with respect to MU levels. At the 2nd milk test, there was a difference of 0.10 percentage points between total protein concentration of the $\mathrm{MU}_{1}$ and $\mathrm{MU}_{4}$ quartiles. This gap progressively closed as lactation progressed, and from the 9th monthly milk test on, total protein percentages were ordered according to MU concentrations.

A negative association was found between MU level and SCC. Links between SCC and MU concentration followed a constant pattern (Figure 5), such that at any milk test, SCC was inversely ordered with respect to MUN level. The SCC increased as lactation progressed, but the inverse relationship between SCC and MU concentration remained constant. This relationship (i.e., low MU levels associated with high SCC) remained when data were analyzed by lactation number. Average $\mathrm{SCC}$ for $\mathrm{MU}_{1}, \mathrm{MU}_{2}, \mathrm{MU}_{3}$, and $\mathrm{MU}_{4}$ quartiles were 434, 308,256 , and $231(\times 1000) / \mathrm{mL}$, respectively.

\section{Relationships Between Nutritional Parameters and MU Concentration}

A total of 90 distinct herd-month rations representing 42 herds were used in the regression analysis for associations between nutritional variables of the rations and MU concentration. Average herd milk yield and MU concentration in this study were $35.0 \mathrm{~kg} / \mathrm{d}$ per cow (SD = 2.0 ; range $=29.9$ to 39.7$)$ and $15.1 \mathrm{mg}$ of $\mathrm{MUN} / \mathrm{dL}(\mathrm{SD}=$ 1.4 ; range $=11.3$ to 18.4 ), respectively.

Feed group definitions and included feedstuffs are presented in Table 3. Average ration composition by

Table 7. Effects and significance of univariate regression models describing the relationship between nutritional variables of rations fed to milking cows and test-day mean herd MUN concentration (mg/dL).

\begin{tabular}{lclll}
\hline Nutritional variable & Estimate & SE & $P$ & $\mathrm{r}^{2}$ \\
\hline NE, Mcal & -2.21 & 0.64 & 0.001 & 0.13 \\
CP, kg of DM & 6.47 & 1.96 & 0.01 & 0.12 \\
RDP, kg of DM & 6.30 & 1.87 & 0.01 & 0.12 \\
RUP, kg of DM & -1.08 & 3.29 & NS & 0.01 \\
NDF, 1 kg of DM & 3.84 & 1.57 & 0.02 & 0.07 \\
NDF non- , kg of DM & 3.15 & 1.27 & 0.02 & 0.07 \\
NSC, kg of DM & -2.48 & 0.81 & 0.01 & 0.10 \\
NSC:CP ratio & -6.84 & 1.70 & 0.001 & 0.16 \\
NSC:RDP ratio & -30.72 & 8.50 & 0.001 & 0.13 \\
\hline
\end{tabular}

${ }^{1} \mathrm{NDF}_{\mathrm{f}}=\mathrm{NDF}$ from forage; $\mathrm{NDF}_{\text {non-f }}=\mathrm{NDF}$ from sources other than forage. 


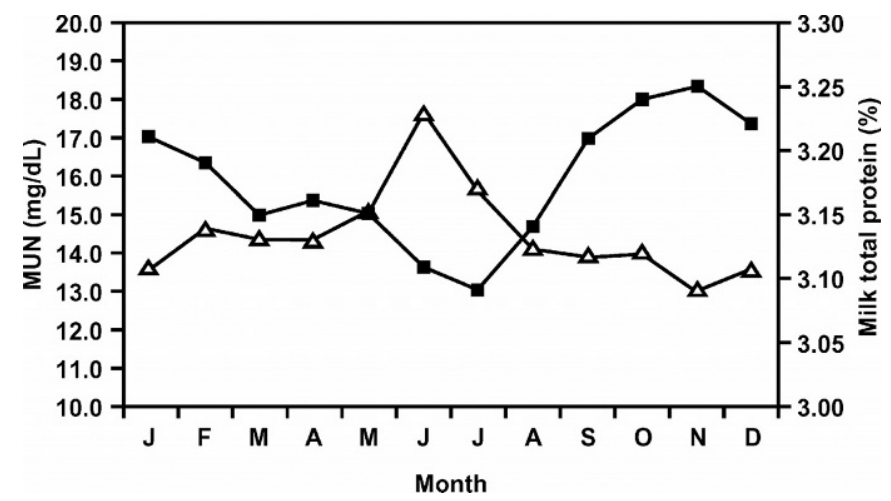

Figure 1. Average MUN $(\triangle)$ and milk total protein tions by month.

feed groups and results of the univariate regression analysis for relationships between feed groups and herd mean MU concentration $(P<0.10)$ are presented in Tables 4 and 5, respectively. Non-protein $\mathrm{N}$ sources (feed group 16), although incorporated in low quantities to the rations, were associated with high MU levels. Other feed groups with similar effects were low-rate degradable protein, fibrous concentrate (low energy), and winter crops harvested as silage. Feed groups associated with low levels of MU were food additives, protein from animal sources, fat, medium-rate degradable protein, low-degradable starch grains, and summer crops harvested as silage.

Summary statistics describing the chemical dietary composition of rations fed to milking cows are presented in Table 6, and associations in univariate analysis between nutritional variables of rations and herd mean MU concentrations are shown in Table 7. Nutrient composition variables with a positive relationship $(P<0.02)$ with MU were CP, RDP, and NDF. To analyze the effect

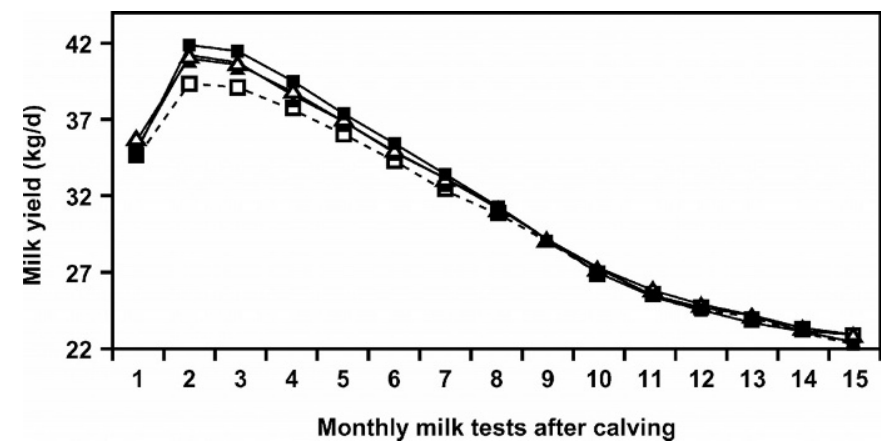

Figure 2. Least squares mean milk yields $(\mathrm{kg} / \mathrm{d})$ in monthly milk tests after calving by MUN quartiles: $\mathrm{MU}_{1}(\square), \mathrm{MU}_{2}(\boldsymbol{\Delta}), \mathrm{MU}_{3}(\triangle)$, and $\mathrm{MU}_{4}(\boldsymbol{\square})$, where $\mathrm{MU}_{1}=<11.75 \mathrm{mg}$ of $\mathrm{MUN} / \mathrm{dL}, \mathrm{MU}_{2}=11.75$ to $14.09 \mathrm{mg}$ of $\mathrm{MUN} / \mathrm{dL}, \mathrm{MU}_{3}=14.10$ to $16.92 \mathrm{mg}$ of $\mathrm{MUN} / \mathrm{dL}$, and $\mathrm{MU}_{4}=>16.92 \mathrm{mg}$ of $\mathrm{MUN} / \mathrm{dL}$.

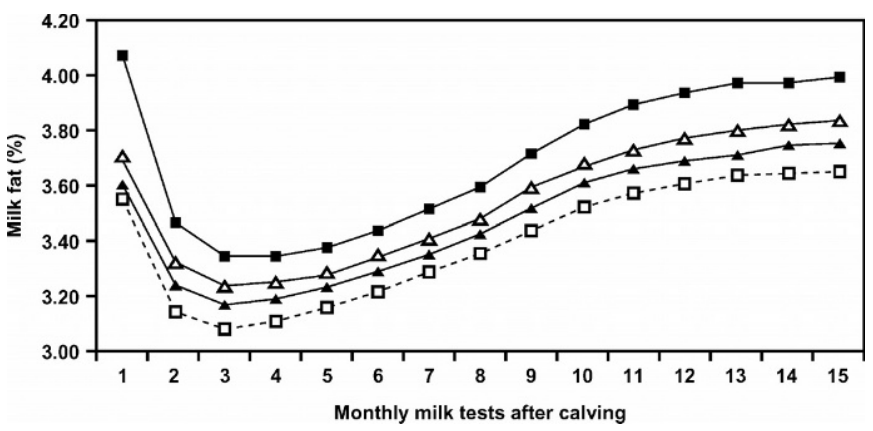

Figure 3. Average fat percentage ( $\mathrm{kg}$ of milk) in monthly milk tests after calving by MUN quartiles: $\mathrm{MU}_{1}(\square), \mathrm{MU}_{2}(\boldsymbol{\Delta}), \mathrm{MU}_{3}(\triangle)$, and $\mathrm{MU}_{4}(\square)$, where $\mathrm{MU}_{1}=<11.75 \mathrm{mg}$ of $\mathrm{MUN} / \mathrm{dL}, \mathrm{MU}_{2}=11.75$ to $14.09 \mathrm{mg}$ of $\mathrm{MUN} / \mathrm{dL}, \mathrm{MU}_{3}=14.10$ to $16.92 \mathrm{mg}$ of $\mathrm{MUN} / \mathrm{dL}$, and $\mathrm{MU}_{4}=>16.92 \mathrm{mg}$ of MUN/dL.

of NDF on MU in more detail, ration total NDF was divided into $\mathrm{NDF}_{f}$ and $\mathrm{NDF}_{\text {non-f }}$ and analyzed separately in univariate models. Both NDF fractions were positively associated $(P<0.02)$ with MU. Nutrient variables with a negative relationship with MU were the NSC:RDP ratio, $\mathrm{NE}_{\mathrm{L}}$, and NSC. The NSC:RDP and NSC:CP ratios, dietary $\mathrm{CP}, \mathrm{RDP}$, and $\mathrm{NDF}_{\mathrm{f}}$ had the strongest associations with MU concentration. Some multivariate models were designed to check relationships of nutritional variables with MU, using a reverse elimination process of non-significant relationships. The model with the best fit included ration energy content $\left(\right.$ Mcal of $\left.\mathrm{NE}_{\mathrm{L}}\right)(P<0.001$; estimate $=-2.0 ; \mathrm{SE}=$ $0.6)$ and $\mathrm{RDP}(\mathrm{kg}$ of $\mathrm{DM})(P<0.06$; estimate $=0.2$; $\mathrm{SE}=0.1$ ).

\section{Relationship Between MU Level of Cows at Insemination and PR}

A total of 36,073 records were included in this study. Mean milk yield at the considered monthly milk test

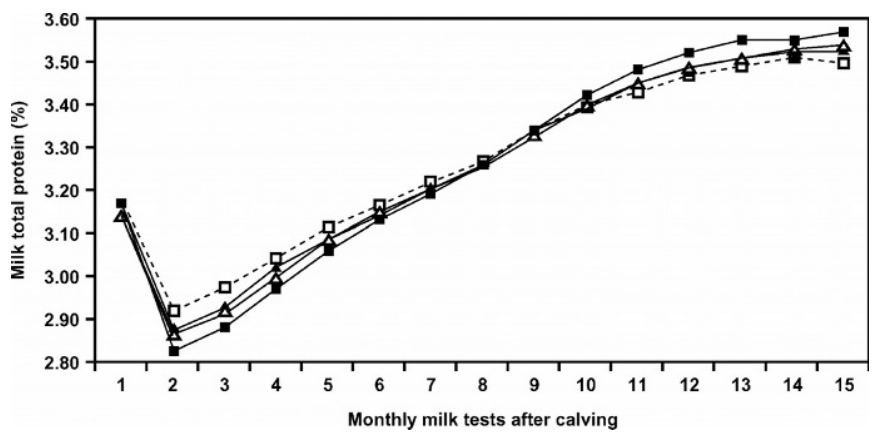

Figure 4. Average total protein percentage (kg of milk) in monthly milk tests after calving by MUN quartiles: $\mathrm{MU}_{1}(\square), \mathrm{MU}_{2}(\boldsymbol{\Delta}), \mathrm{MU}_{3}$ $(\triangle)$, and $\mathrm{MU}_{4}(\square)$, where $\mathrm{MU}_{1}=<11.75 \mathrm{mg}$ of $\mathrm{MUN} / \mathrm{dL}, \mathrm{MU}_{2}=11.75$ to $14.09 \mathrm{mg}$ of $\mathrm{MUN} / \mathrm{dL}, \mathrm{MU}_{3}=14.10$ to $16.92 \mathrm{mg}$ of $\mathrm{MUN} / \mathrm{dL}$, and $\mathrm{MU}_{4}=>16.92 \mathrm{mg}$ of $\mathrm{MUN} / \mathrm{dL}$. 


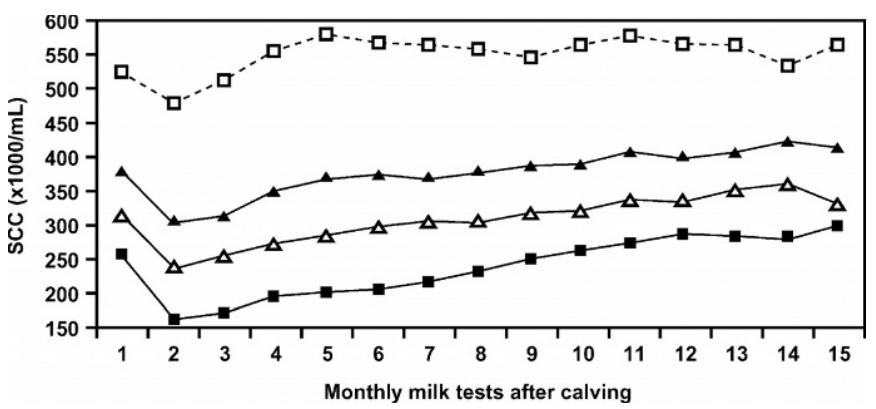

Figure 5. Average SCC $(\times 1000 / \mathrm{mL}$ of milk $)$ in monthly milk tests after calving by MUN quartiles: $\mathrm{MU}_{1}(\square), \mathrm{MU}_{2}(\boldsymbol{\Delta}), \mathrm{MU}_{3}(\triangle)$, and $\mathrm{MU}_{4}(\boldsymbol{\square})$, where $\mathrm{MU}_{1}=<11.75 \mathrm{mg}$ of $\mathrm{MUN} / \mathrm{dL}, \mathrm{MU}_{2}=11.75$ to 14.09 $\mathrm{mg}$ of $\mathrm{MUN} / \mathrm{dL}, \mathrm{MU}_{3}=14.10$ to $16.92 \mathrm{mg}$ of $\mathrm{MUN} / \mathrm{dL}$, and $\mathrm{MU}_{4}=$ $>16.92 \mathrm{mg}$ of $\mathrm{MUN} / \mathrm{dL}$.

was $38.9 \mathrm{~kg} / \mathrm{d}$, and mean days from calving to insemination were 116. The cows were categorized into four quartiles based on MUN values: $\mathrm{MU}_{1}<11.75 \mathrm{mg} / \mathrm{dL}$, $\mathrm{MU}_{2}=11.75$ to $14.09 \mathrm{mg} / \mathrm{dL}, \mathrm{MU}_{3}=14.10$ to 16.92 $\mathrm{mg} / \mathrm{dL}$, and $\mathrm{MU}_{4}>16.92 \mathrm{mg} / \mathrm{dL}$. Average PR for first, second, and third inseminations were 41.0, 36.9, and $31.7 \%$, respectively. The mean MU value for all cows was $14.9 \mathrm{mg}$ of MUN/dL. Mean MU concentrations for cows that were confirmed pregnant and for cows that were not confirmed pregnant as a result of the respective insemination were 14.9 and $15.0 \mathrm{mg}$ of MUN/dL, respectively. Variables in the model $\left(\mathrm{R}^{2}=0.06\right)$ that significantly influenced PR were MU level $(P<0.04)$, herd $(P<0.001)$, month of insemination $(P<0.001)$, year $(P<0.01)$, dystocia at previous calving $(P<0.001)$, insemination number $(P<0.001)$, parity $(P<0.01)$, days from calving to insemination $(P<0.04)$, and the interaction between insemination number and parity $(P$ $<0.01)$. Milk yield did not have a statistically significant effect on PR $(P<0.14)$. Least squares mean $\mathrm{PR}$ for $\mathrm{MU}_{1}$, $\mathrm{MU}_{2}, \mathrm{MU}_{3}$, and $\mathrm{MU}_{4}$ quartiles were 38.4, 37.0, 36.2 and $36.1 \%$, respectively (Figure 6). Therefore, high MU values were associated with lower PR.

\section{DISCUSSION}

\section{Relationships Between Production and Environmental Factors and MU Concentration}

Associations of production and environmental factors with MU concentration were examined at the cow level using a large $(\mathrm{n}=1,279,600)$ database. In Model 1 , MU was a continuous variable; in Model 2, data were categorized into four quartiles based on MUN values to enable an analysis of milk yield, milk fat and total protein contents, and SCC for different levels of MU. Production and environmental factors explained $37 \%$ of the MU variation in individual cows.

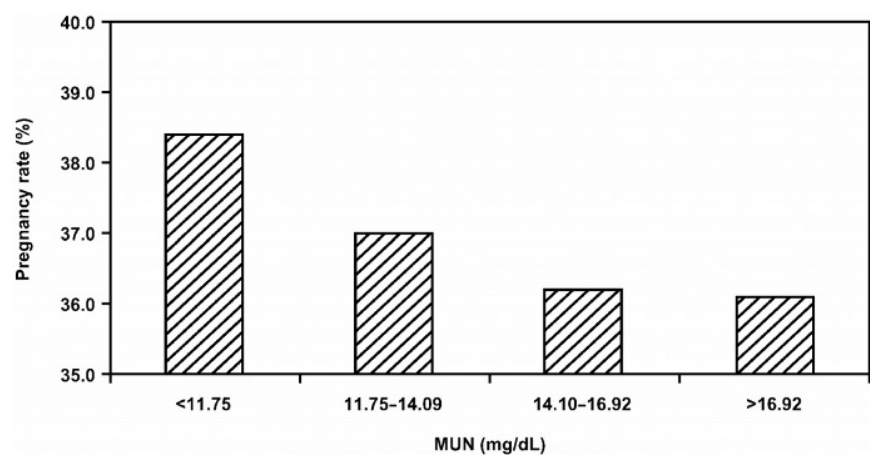

Figure 6. Relationship of MUN concentration measured $\pm 5 \mathrm{~d}$ from AI to pregnancy rate for 1st through 3rd inseminations in lactating cows.

Milk yield. There was a positive association $(P<$ 0.001 ) between MU concentration and milk yield. This relationship (Figure 2) was larger at lactation peak then progressively diminished as lactation progressed. These findings agree with previous reports by RajalaSchultz and Saville (2003) for high-producing herds. Other studies examininig the relationship between milk yield and MU level found either no significant correlation between these parameters (Gustafsson and Carlsson, 1993; Butler et al., 1995; Godden et al., 2001) or a negative link (Broderick and Clayton, 1997). Milking cows in Israel are generally fed the same ration throughout lactation. When examining the relationship between herd mean milk yield and herd mean MU concentration, we found high-producing herds with mean MUN concentrations of 9 to $10 \mathrm{mg} / \mathrm{dL}$, which suggests that protein feeding efficiency can be effectively monitored without compromising yields.

Milk fat percentage. There was a consistent positive association between MU and milk fat content. On all of the monthly test days (Figure 3), average fat percentages for the different quartiles were in direct correspondence with MU levels. Similar findings have been reported by Godden et al. (2001) and by RajalaSchultz and Saville (2003) for high-producing herds. A possible explanation for this association could be that high amounts of $\mathrm{NDF}_{\mathrm{f}}$ may increase milk fat content and at the same time raise MU levels (Table 7) because of the high degradability of its protein. Nevertheless, considering that the degree of variation in $\mathrm{NDF}_{\mathrm{f}}$ content in Israeli rations for milking cows is very narrow (Table 6), that supposition would not suitably explain the tight link found between milk fat content and MU.

Milk total protein percentage. There was a negative association between MU and milk total protein content (Table 2). At the beginning of lactation (Figure 4 ), total protein percentages were ordered inversely with respect to MUN levels, but the gap gradually 
closed as lactation progressed, and from the 9th monthly milk test on, total protein percentages were ordered according to MU concentration. Previous studies (Godden et al., 2001; Rajala-Schultz and Saville, 2003) found no significant relationship between milk total protein and MU. Variations of MU (Table 2) and milk total protein (Figure 4) followed a similar pattern at the beginning of lactation and up to late lactation. At the 2nd monthly milk test, both parameters were at their nadir, and from then on their levels increased. After 300 DIM, the tendencies of both variables diversified; MU leveled off and then decreased, and total protein content continued to rise. Trends of milk total protein and MU during the year had inverse signs. At late spring and early summer, MU peaked, and milk total protein was at its lowest level (Figure 1), in accordance with Ferguson et al. (1997). The inverse relationship between MU and milk total protein pinpoints the alternative pathways that $\mathrm{N}$ can follow: incorporation into milk protein or excretion as urea.

SCC. A strong negative relationship was found between MU and SCC. At all of the examined monthly milk tests (Figure 5), SCC followed MU concentrations in an inverse order. This pattern was also evident when data were considered by MU quartile and by parity. This conclusion agrees with previous reports by Godden et al. (2001) and Rajala-Schultz and Saville (2003), but is puzzling in that those variables refer to physiological processes that are not clearly connected. Milk urea is related to protein and NPN supply and their utilization rate in the rumen; SCC reflects the degree of irritation in the udder.

Parity. Milk urea concentration was lower in first lactation cows than in second lactation cows by $0.50 \mathrm{mg}$ of MUN/dL (Table 1). This difference could be partially explained by the combined effects of parity and milk yield ( 0.19 and $0.12 \mathrm{mg}$ of MUN/dL, respectively) (Table 2 ). Those findings agree with the tendency reported by Butler et al. (1995), Carlsson et al. (1995), and RajalaSchultz and Saville (2003).

Month of lactation. On the 2nd monthly test day, MU concentration was at its lowest level (least squares mean $=13.5 \mathrm{mg}$ of MUN/dL). From then on, MU level progressively increased until 300 DIM (least squares mean $=14.7 \mathrm{mg}$ of $\mathrm{MUN} / \mathrm{dL}$ ) and then leveled off and decreased toward the end of lactation. These findings are in accordance with reports by Carlsson et al. (1995), who found that MU was lowest immediately after calving, increased, reached a maximum between 3 and 6 mo of lactation, and then slowly declined.

Month of the year. Milk urea was at its lowest level in November (least squares mean $=11.8 \mathrm{mg}$ of MUN/ $\mathrm{dL}$ ), increased in the winter and spring months, and reached a maximum in June (least squares mean $=18.1$ $\mathrm{mg}$ of MUN/dL). From that point, MU concentration progressively diminished to the autumn-winter level. Israeli dairy cows are kept indoors throughout the year and fed a TMR of relatively constant composition that generally does not include fresh-cut grass. Therefore, the seasonal influence on MU concentration appears to be a direct one.

\section{Relationships Between Nutritional Parameters and MU Concentration}

Two data subsets including a total of 90 herd-month, programmed TMR representing 42 non-grazing herds were used to check associations between nutritional variables and MU. A total of 46 feedstuffs were registered and merged into 17 feed groups according to nutritional parameters. Results from the univariate analysis, at mean herd level, showed that NPN sources (feed group 16) significantly $(P<0.003)$ increased MU levels, suggesting that the supply of $\mathrm{N}$ to the rumen exceeded the flora's capacity to incorporate it into anabolic processes. Our findings suggest that if NPN sources are incorporated into rations, attention has to be given to the balance between $\mathrm{N}$ supply and available energy sources at rumen level to minimize $\mathrm{N}$ losses. Corn gluten meal (feed group 10) was associated $(P<0.03)$ with high MU levels, a result that persisted when the two data subsets were analyzed separately. This finding does not correspond with the general consideration that corn gluten meal protein is of low degradability in the rumen and hints at the need for carefully checking the quality of this product, which is regularly imported to Israel. Other feeds positively correlated with MU level were soybean hulls (feed group 13) and wheat silage (feed group 4), which is the main forage in Israeli rations for dairy cows. Feed groups associated with low levels of MU were protein from animal sources, fat, medium-rate degradable protein, low-degradable starch grains, and summer crops harvested as silage. The effect of fat on MU disagrees with previous conclusions by DePeters and Cant (1992). Food additives, a feed group including substances with buffering activity (sodium bicarbonate, magnesium oxide), might have affected MU level by their action on ruminal $\mathrm{pH}$.

Mean herd MU showed a positive relationship $(P<$ 0.02 ) with ration $\mathrm{CP}, \mathrm{RDP}, \mathrm{NDF}_{\mathrm{f}}$, and $\mathrm{NDF}_{\text {non-f. }}$. Associations between MU and both $\mathrm{CP}$ and RDP dietary level have been widely reported (Gustafsson and Carlsson, 1993; Baker et al., 1995; Butler et al., 1995). In our study, the effect of CP on MU was 2- to 3-fold that reported by Broderick and Clayton (1997) and Godden et al. (2001). Nutrient composition variables with a negative relationship with $\mathrm{MU}$ were $\mathrm{NE}_{\mathrm{L}}$ and NSC. Energy content of the ration was related $(P<0.001)$ to low 
MU levels. It is suggested that an increased supply of available energy to the ruminal flora enhances anabolic processes that contribute to decreasing $\mathrm{N}$ losses from the rumen. Because the NSC fraction is a large contributor to the energy content of the ration, the effects of both variables on MU are closely associated. No significant association was found between RUP and MU. The NSC:RDP and NSC:CP ratios showed a strong negative association with MU. The multivariate model with the best fit for herd mean $\mathrm{MU}$ included $\mathrm{NE}_{\mathrm{L}}$ and $\mathrm{RDP}$ supply of the ration, stressing that the main nutritional factors affecting MU level are the amount of $\mathrm{N}$ that solubilizes in the rumen and its captation rate by the ruminal flora, which largely depends on an adequate energy supply.

\section{Relationship Between MU Level of Cows at Insemination and PR}

This study was designed to examine the association between the MU level of a cow close to insemination $( \pm 5 \mathrm{~d})$ and PR. The analyzed data file included 36,048 records and was obtained from the Israeli DHI Center, which assembles laboratory milk-test results and fertility reports, including pregnancy-checking results. A significant $(P<0.04)$ negative association was found between MU level and PR. Least squares mean PR for the $\mathrm{MU}_{1}, \mathrm{MU}_{2}, \mathrm{MU}_{3}$ and $\mathrm{MU}_{4}$ quartiles were 38.4, 37.0, 36.2 , and $36.1 \%$, respectively. Our results show a progressive reduction of $\mathrm{PR}$ at increasing $\mathrm{MU}$ levels. The difference in $\mathrm{PR}$ between the $\mathrm{MU}_{1}$ and $\mathrm{MU}_{4}$ quartiles was 2.3 percentage points. Previous studies have reported a connection between high MU or SU and reduced reproductive efficiency (Gustafsson and Carlsson, 1993; Butler et al., 1996; Rajala-Schultz et al., 2000 ), but, in other investigations, that effect was not found (Butler et al., 1995; Garcia-Bojalil et al., 1998; Melendez et al., 2000). Butler et al. (1996) reported that cows $(\mathrm{n}=155)$ with $>19 \mathrm{mg}$ of MUN/dL on the day of AI showed a reduction of 21 percentage points relative to cows with lower MUN levels. Larson et al. (1997) reported that cows with MU concentrations $>21 \mathrm{mg}$ of MUN/dL at breeding $(n=228)$ were more likely to not become pregnant. In these two studies, the negative influence of MU on fertility happened at higher levels than the findings in the present research. In our study, $\mathrm{PR}$ in cows with $<11.75 \mathrm{mg}$ of MUN/dL was 1.4 percentage points higher than that in cows with 11.75 to 14.09 $\mathrm{mg}$ of MUN/dL, in close agreement with Gustafsson and Carlsson (1993) ( $\mathrm{n} \geq 1000)$, who reported an impairment of reproductive parameters for MUN levels higher than $15 \mathrm{mg} / \mathrm{dL}$, and with Rajala-Schultz et al. (2000) ( $\mathrm{n}=1249$ ), who found that cows with $<10 \mathrm{mg}$ of MUN/ $\mathrm{dL}$ were 1.7 times more likely to be pregnant than cows with MUN levels between 10.0 and $12.7 \mathrm{mg} / \mathrm{dL}$ and 2.4 times more likely to be pregnant than cows with MUN levels $>15.4 \mathrm{mg} / \mathrm{dL}$.

Our findings indicate that increasing levels of $\mathrm{MU}$ are negatively related to reproductive performance of dairy cows and that this effect can be detected at MU levels lower than generally reported. However, the risk of nonpregnancy because of high levels of MU was lower than found in previous studies.

\section{CONCLUSIONS}

The present study examined productive, environmental, and nutritional factors that influence MU levels using field data from high-yielding cows kept constantly indoors and fed TMR. It has been recommended that MU be interpreted at the herd or group level because of the large variation observed in MU measurements among individual cows. Nevertheless, the use of MU measurements to monitor the efficiency of dietary protein utilization requires the identification and quantification of factors other than nutritional ones that influence MU. Production and environmental factors were responsible for $37 \%$ of the MU variation at the individual cow level. Milk urea was positively associated with milk yield and milk fat content and negatively related to milk total protein percentage and SCC. Relationships between MU and fat and SCC were particularly strong and steady throughout the lactation. The inverse relationship between $\mathrm{MU}$ level and milk total protein was particularly evident when their simultaneous annual variation was analyzed. Milk urea was lower in first lactation cows and fluctuated during the year, being higher at the onset of the hot season.

Benefits of the identification and correction of nutritional imbalances that cause $\mathrm{N}$ losses may include more efficient use of dietary protein, which could result in lower production costs and increased profitability, and a reduction in avoidable mineral losses to the environment. Nutrient composition variables having a positive relationship $(P<0.02)$ with mean herd MU were $\mathrm{CP}$, $\mathrm{RDP}, \mathrm{NDF}_{\mathrm{f}}$, and $\mathrm{NDF}_{\text {non-f; }}$; energy content of the ration and NSC were negatively associated with MU. When nutrient factors influencing MU were analyzed in multivariate models, the best fit was obtained when the model included the $\mathrm{NE}_{\mathrm{L}}$ and $\mathrm{RDP}$ supply in the ration, stressing that the main factors affecting MU level are the amount of $\mathrm{N}$ that solubilizes in the rumen and the energy supply to the ruminal flora. The effect of specific feed groups on MU level showed significant influences that may be taken into consideration while attempting to minimize $\mathrm{N}$ losses. In general, the relationship of group feed to MU concentration was consistent with commonly accepted values regarding chemical composi- 
tion and protein ruminal degradability of feeds. Nonprotein $\mathrm{N}$ and feeds characterized by high NDF content, relatively low energy values, and a rather low ruminal degradability were positively associated with MU.

An additional objective of this study was to examine the association between the MU level in cows close to insemination and reproductive efficiency. Least squares mean PR for cows in the lowest and highest MU quartiles were 38.4 and $36.1 \%$, respectively. Increasing levels of MU were negatively related to reproductive performance of dairy cows, but the risk of nonpregnancy because of high levels of MU was lower than reported in previous studies.

\section{REFERENCES}

Baker, L. D., J. D. Ferguson, and W. Chalupa. 1995. Responses in urea and true protein of milk to different protein feeding schemes for dairy cows. J. Dairy Sci. 78:2424-2434.

Broderick, G. A., and M. K. Clayton. 1997. A statistical evaluation of animal and nutritional factors influencing concentrations of milk urea nitrogen. J. Dairy Sci. 80:2964-2971.

Butler, W. R., J. J. Calaman, and S. W. Beam. 1996. Plasma and milk urea nitrogen in relation to pregnancy rate in lactating dairy cattle. J. Anim. Sci. 74:858-865.

Butler, W. R., D. J. R. Cherney, and C. C. Elrod. 1995. Milk urea nitrogen (MUN) analysis: field trial results on conception rates and dietary inputs. Page 89 in Proc. Cornell Nutr. Conf., Rochester, NY. Cornell Univ., Ithaca, NY.

Carlsson, J., J. Bergstrom, and B. Pehrson. 1995. Variations with breed, age, season, yield, stage of lactation and herd in the concentration of urea in bulk milk and individual cow's milk. Acta Vet. Scand. 35:67-77.

DePeters, E. J., and J. P. Cant. 1992. Nutritional factors influencing the nitrogen composition of bovine milk: A review. J. Dairy Sci. 75:2043-2070.

Ferguson, J. D., N. Thomsen, D. Slesser, and D. Burris. 1997. Pennsylvania DHIA milk urea testing. J. Dairy Sci. 80(Suppl.1):161. (Abstr.)
Garcia-Bojalil, C. M., C. R. Staples, C. Risco, J. D. Savio, and W. W. Tatcher. 1998. Protein degradability and calcium salts of longchain fatty acids in the diets of lactating dairy cows: reproductive responses. J. Dairy Sci. 81:1385-1395.

Godden, S. M., K. D. Lissemore, D. F. Kelton, K. E. Leslie, J. S. Walton, and J. H. Lumsden. 2001. Relationships between milk urea concentrations and nutritional, management, production and economic variables in Ontario dairy herds. J. Dairy Sci. 84:1128-1139.

Gustafsson, A. H., and J. Carlsson. 1993. Effects of silage quality, protein evaluation systems and milk urea content on milk yield and reproduction in dairy cows. Livest. Prod. Sci. 37:91-105.

Hof, G., M. D. Vervoorn, P. J. Lenaers, and S. Tamminga. 1997. Milk urea nitrogen as a tool to monitor the protein nutrition of dairy cows. J. Dairy Sci. 80:3333-3340.

Howard, H. J., E. P. Aalseth, G. D. Adams, L. J. Bush, R. W. McNew, and L. J. Dawson. 1987. Influence of dietary protein on reproductive performance of dairy cows. J. Dairy Sci. 70:1563-1571.

Kohn, R. A., K. F. Kalscheur, and E. Russek-Cohen. 2001. Evaluation of models to estimate urinary nitrogen and expected milk urea nitrogen. J. Dairy Sci. 85:227-233.

Larson, S. F., W. R. Butler, and W. B. Currie. 1997. Reduced fertility associated with low progesterone postbreeding and increased milk urea nitrogen in lactating cows. J. Dairy Sci. 80:1280-1295.

Melendez, P., A. Donovan, and J. Hernandez. 2000. Milk urea nitrogen and infertility in Florida Holstein cows. J. Dairy Sci. 83:459-463.

National Research Council. 1989. Nutrient Requirements of Dairy Cattle. 6th rev. ed. Update. 1989. National Academy Press, Washington, DC.

Ørskov, E. R. 1989. Optimising rumen function: getting the best out of feeds. Pages 101-108 in Ruminant Feed Evaluation and Utilisation. B. A. Stark, J. M. Wilkinson, and D. I. Givens, ed. Chalcombe Publications, Aberystwth, UK.

Rajala-Schultz, P. J., and W. J. A. Saville. 2003. Sources of variation in milk urea nitrogen in Ohio dairy herds. J. Dairy Sci. $86: 1653-1661$.

Rajala-Schultz, P. J., W. J. A. Saville, G. S. Frazer, and T. E. Wittum. 2000. Association between milk urea nitrogen and fertility in Ohio dairy cows. J. Dairy Sci. 84:482-489.

Rodriguez, L. A., C. C. Stallings, J. H. Herbein, and M. L. McGilliard. 1997. Effect of degradability of dietary protein and fat on ruminal, blood and milk components of Jersey and Holstein cows. J. Dairy Sci. 80:353-363.

SAS. 1999-2001. SAS User's Guide: Statistics. Release 8.2. SAS Inst., Inc., Cary, NC. 